\title{
Introduction
}

\section{Eli MacLaren*}

The essays in this issue of the Papers of the Bibliographical Society of Canada I Cahiers de la Société bibliographique du Canada proceed from papers delivered at the Fourth National Conference on the State of Canadian Bibliography, held at the Bibliothèque et Archives nationales du Québec in Montreal from 20 to 22 June 2007. The descriptive title of the conference, "Beyond the Text: Bibliography in the Digital Age," suggested the following topic: how has twentyfirst-century computer technology changed the practices commonly associated with books - the collection and preservation of them in libraries, the writing and publishing of them, and the study of them as artifacts? These questions were addressed. As session succeeded session, however, speakers responded equally to the broader topic implied in the serial title of the conference, surveying and evaluating the current approaches to bibliography. Evidently there was a need to take stock of book studies - to consider the impact of computers without focusing on them alone and to reflect on the surge of scholarly curiosity and achievement in the field of book history. The result is this collection, a discussion in seven parts of the bibliographical discipline as it is manifest in research and library practice today.

Three questions arise for debate among the following essays. The first regards the relation of bibliography to book history. Are they separate disciplines? The question may be put as a problem of definitions. "Bibliography" commonly refers to the identification, listing, and description of a class of books. This general definition encompasses more specialized usages, in which "descriptive bibliography," the observation of the physical attributes of books for the purpose of precisely determining how they were made and used, differs from "catalogue," a simple list of authors, titles, and

* Eli MacLaren is a SSHRC post-doctoral fellow in the Department of English at Queen's University. He completed his doctoral dissertation, "Copyright and the Prevention of Literary Publishing in English Canada, I867-1920," in the Collaborative Program in Book History and Print Culture at the University of Toronto in 2007. 
publication information. But given recent developments in academic research, does "bibliography" now also mean "book history" - or is the latter something new? In his discussion, Nick Mount points to hiring patterns and differences between green and hoary scholarly associations as evidence of a basic split: universities are hiring candidates with expertise in book history, and the novelty of this field is patent in the recent flourishing of the Society for the History of Authorship, Reading and Publishing (SHARP). This view accords with Jonathan Rose's vision of book history as a "new academic frontier":

Historians have always used documents to reconstruct the past, but only in the closing years of the twentieth century did they come to understand that documents themselves have histories. They had not truly appreciated that earlier, no more than a fish appreciates the water. But certainly after Elizabeth Eisenstein's The Printing Press as an Agent of Change (1979) historians began to ask, in a methodical way, how the vast mountains of paper called into existence by all literate societies were created, reproduced, disseminated, read, stored, and (in some cases) destroyed. ${ }^{\mathrm{I}}$

In contrast, in her essay here Patricia Lockhart Fleming sees bibliography and book history as essentially one and cites an earlytwentieth-century example of their interdependence. If as early as I952 Marie Tremaine methodically listed certain books and described their physical form while situating their production and reception in a wider social context using collateral evidence (archival and printed), then the hailing of book history as an invention of the last thirty years is surely exaggerated. "In discovering what was published (even what was projected for, but failed of publication), one might gain a useful view of the activities and preoccupations of a little society," wrote Tremaine in her preface, and this is exactly what her landmark work on British North America delivered - a general portrait of authorship, printing, publishing, and reading in the colonies that would become Canada, traced from hundreds of documents precisely observed. ${ }^{2}$

Rose articulates what he sees as the breakthrough of book history in another way. Literary scholars once focused on works of great beauty but then shifted their emphasis to the political ramifications

I Jonathan Rose, "The Horizon of a New Discipline: Inventing Book Studies," Publishing Research Quarterly I9 (Spring 2003): II.

2 Marie Tremaine, A Bibliography of Canadian Imprints, I75I-I800 (Toronto: University of Toronto Press, 1952), v. 
of texts, in order to show how language constructs social categories (including "the beautiful"); now, however, they have overwhelmingly recognized that "language" is itself inextricable from economics and that the power of texts cannot be accurately interpreted without an understanding of the transactions that have determined their material form: "It is perfectly legitimate to ask how literature has shaped history and made revolutions, how it has socially constructed race, class, gender, and so on. But we cannot begin to answer any of these questions until we know how books (not texts) have been created and reproduced, disseminated and read, preserved and suppressed." 3 Of course, knowing about the production and dissemination of books has long been the province of descriptive bibliography. Fredson Bowers held the illumination of publishing history to be a central purpose of bibliographical description. In every good bibliography, "Interpretation should be made of any features of the description which bear on the method of printing and publication of the entire book or any part of it, with the main purpose of revealing the composition and the transmission of the text." 4 Granted, he is referring here to any particular book rather than the book as a cultural phenomenon, but how can one see the whole except through scrutinizing the parts? The accurate and precise description of specific books was of crucial importance to Bowers; nevertheless, he still considered it only a means serving larger ends, such as textual editing, literary interpretation, and history. Moreover, the "popularity of an author" - the phenomenon of reading - was another "important historical matter" that Bowers considered bibliography capable of evaluating. ${ }^{5}$ Linda Quirk arrives at the same conclusion in her thoughts below, demonstrating how bibliography serves as a way to clarify things of interest to literary criticism (such as the career of the Canadian author, Sara Jeannette Duncan, and the genre of writing that she preferred). Not the mere amassing of measurements but the interpretation of them in order to illuminate history has been the express intention of descriptive bibliographers and remains so.

If the investigation of book production and reception is not new, why the current buzz? Rose further characterizes book history as exceptionally interdisciplinary. ${ }^{6}$ Here may lie the key. The impact

\footnotetext{
3 Rose, "Horizon of a New Discipline," I3.

4 Fredson Bowers, Principles of Bibliographical Description (1949; repr., New York: Russell and Russell, 1962), I8.

5 Ibid., 9-IO, I5, 34, 34n34, I5ni6.

6 Rose, "Horizon of a New Discipline," I9.
} 
of sociology upon history, in particular the impulse to account for broad social change by recourse to statistics, propelled the study of publishing and reading into a new dimension. Thus Robert Darnton achieved an ambitious account of pre-revolutionary France and its absorption of Enlightenment ideas by working from the letters and numerical accounts of an especially well-preserved publisher's archive. ${ }^{7}$ Cultural studies, the subjective critique of hegemony through the interpretation of all sorts of objects, brought immense energy to the inquiry into how material forces shape people's identity and their beliefs, seizing upon the book as an especially palpable intersection of commerce and culture. Thus Janice A. Radway analyzed the publishing and reception of paperback romances in order to grasp how middle-class American women negotiate patriarchy. ${ }^{8}$ Social history, cultural studies, and other widespread intellectual movements of the later twentieth century converged on the traditional domain of bibliography and opened it up to unprecedented academic popularity under the name of "book history."

Leslie Howsam's model of book history emphasizes this convergence of disciplines instead of the novelty of any one. If book history is a triangle, bibliography is one foundational corner of it, history and literature being the other two. ${ }^{9}$ This moderate view answers the question of definitions in an attractive way: "book history" includes "bibliography." At the end of his essay included here, David Vander Meulen arrives at a comparable idea of inclusion, stating that the study of books should encompass both physical and sociological evidence in order to furnish a whole historical account: "without both of them, that totality is narrowed." In light of these models of inclusion, the persistence of the question of disciplinary separation becomes a mere matter of perspective. Each corner of Howsam's triangle has something of its own language, and bibliography, or "writing about books," is no exception. The symbols and terms of descriptive bibliography give names to objects, allowing us to think about them in their absence. Like all languages, it must be learned through the repeated association of symbol and object. A teacher is invaluable in this process. If the language is not learned, a curtain

7 Robert Darnton, The Business of Enlightenment: A Publishing History of the Encyclopédie, I775-I80o (Cambridge: Belknap Press, 1979).

8 Janice A. Radway, Reading the Romance: Women, Patriarchy, and Popular Literature (Chapel Hill: University of North Carolina Press, 1984).

9 Leslie Howsam, Old Books and New Histories: An Orientation to Studies in Book and Print Culture (Toronto: University of Toronto Press, 2006), Io. 
comes down over that corner of the book-history triangle: those who think descriptive bibliography extraneous to book history are those who have not learned the language. But in the same breath it must be added that competency in any language is measured on a spectrum, not in all-or-nothing categories. If only a few care to master the language, many still benefit from wielding (to use Mount's term) what they need of it: descriptive bibliography sheds light on the world of books incrementally as one appropriates its symbols and terms. ${ }^{\mathrm{IO}}$

The second question for debate concerns evaluation. What has bibliography recently accomplished and what consequently are its prospects? Three essays distill the achievements of the newly completed History of the Book in Canada / Histoire du livre et de l'imprimé au Canada (HBiC/HLIC), the collaborative national book-history project that sprang out of the 1995 meeting of the Bibliographical Society of Canada. Patricia Lockhart Fleming, the director of the project and a general editor, observes that it has created a community of Canadian book historians. One hundred and seventy-two authors from across Canada contributed, and collaboration increased as the project progressed. Seventy graduate students or post-doctoral fellows were trained to undertake research for the project, and this training ensures the future of the discipline. Fleming goes on to measure $\mathrm{HBiC} / \mathrm{HLIC}$ against the standards for book history that Michael F. Suarez has recently articulated. It was genuinely interdisciplinary. The periodization (the practical division of the research into three eras, ending I840, I9I8, and I980) was not arbitrary but rather adhered to wider phases of Canadian social history. The objects of study were all sorts of imprints, not literature only. Bibliographical methods were employed, and the editors did not pretend to exhaust the field of inquiry. Many methods were employed to approach the difficult history of reading. Significantly too, the three published volumes that have resulted from the project are affordable and accessible in both of Canada's official languages.

Yvan Lamonde, the other general editor, identifies the insights and breakthroughs of $\mathrm{HBiC} / \mathrm{HLIC}$ from the point of view of a historian. He singles out articles that have advanced our knowledge of specific topics, but also points to the advantage of a publicly funded, national project that obliged authors to move beyond their specializations. The result is an apprehension of broader trends.

Io One of the best places to start remains Philip Gaskell's New Introduction to Bibliography (1972; repr., New Castle, DE: Oak Knoll Press, 1995). 
Thus the centrality of the Roman Catholic church to the book in nineteenth-century Quebec aligns with the success of Protestant printing operations in Ontario at the same time to indicate a larger Canadian phenomenon - the Word impressed, that is, the religious imprint and its exceptional success in contrast to other categories of local publication, such as the literary. The $\mathrm{HBiC} / \mathrm{HLIC}$ synthesis also explains as never before the interrelated causes of Canada's post-I880 "take off." Lamonde argues that demographic "agglomeration" in the later nineteenth century, by improving schools and literacy, facilitated an advertisement-based mass production that subsequently both drove and pursued the leaping westward expansion of modern Canada. Only an interdisciplinary project of national scope could have achieved such a comprehensive view of the social, the technological, and the economic at once.

The computer's contribution to HBiC/HLIC is summarized by Bertrum H. MacDonald, the project's electronic resources editor. The coinciding of the project with the rapid development of the Internet was not lost upon the editors, and five bilingual and publicly accessible online databases were developed to apply the power of new technology to Canadian book history. The first compiles secondary sources on the topic of Canadian book history. The second lists a special category of primary sources - catalogues, whether of publishers, booksellers, libraries, or auctions. The third, currently focused on the eighteenth and nineteenth centuries, is a directory of the thousands of people known to have worked in the book trade and libraries in Canada. The fourth is a list of all known early-Canadian imprints - books, pamphlets, broadsides, serials, and government documents printed in the British North American colonies from I752 to I840. The fifth isolates another important category of primary sources - textbooks. These fully searchable databases, which are at various stages of development, have already enabled research that would not have been possible without them; they will continue to grow when transferred to the management of Library and Archives Canada (LAC) in the near future. If the accomplishments of $\mathrm{HBiC} / \mathrm{HLIC}$ are any indication, the current prospects for the study of books are manifold and bright.

David Vander Meulen organizes these prospects into three categories of opportunity lying before the descriptive bibliographer today. First, there is conventional description, the examination of printed books using traditional techniques. These techniques, such as the comparison of the running titles in different copies for evidence of variation within an edition, use sight and touch to illuminate the 
processes of typesetting and presswork behind a book. Although the techniques are not new, most books have not yet been described conventionally, and it is therefore important that libraries remain focused on preserving printed books. Second, there is computerassisted description, the examination of printed books using new technology. Besides creating databases, computers could be used to recognize typefaces, measure spacing, measure chain lines, and accelerate many other tedious tasks. Third, there is the description of electronic books and computers themselves. This analysis poses the greatest challenge to traditional bibliographers but the prevalence of electronic texts today makes it urgent, as the electronic forging of George W. Bush's military record shows.

Nowhere is the urgency more keenly felt than in libraries. What to the academic researcher is a rich field of inquiry is a daunting avalanche of work to the librarian. The flourishing of the Internet, electronic publishing, and the resultant geometric increase in the number of published documents pose immediate challenges for an official cultural repository such as LAC, whose task it is to describe and collect the totality of publications within its mandated sphere. Ingrid Parent, Assistant Deputy Minister for the Documentary Heritage Collection Sector at LAC, speaks to these bibliographic challenges in her concluding remarks. Some strategies are in place: LAC is contributing to the international bibliography, Book History Online, and developments abroad in the practice of national bibliography are being monitored closely. But how can libraries adapt to the sheer number of electronic publications? Increasing library funding is the obvious answer, but Parent outlines two approaches that may be considered in the meantime - to simplify the bibliographical description of each document, and to find partners willing to produce descriptions. The recent trend in the Internet of user-generated content raises the interesting question of whether users may begin to contribute to national bibliographies. The debate of such questions must begin, for the evidence of a transition in communication is all around us.

The third question debated at the conference and in the following essays regards the breadth and depth of this transition. Is there an electronic or digital revolution? Besides those whose thoughts are recorded below, the conference heard from David McKnight, Lise Bissonnette, Richard Landon, Thomas Hickerson, Robert Cole, Chris Hackett, Mary Kandiuk, John Meier, Carl Spadoni, Jean-René Lassonde, and Ernie Ingles, and the opinions on this question diverged 
starkly. Again the divergence appears to be a matter of perspective. A profound transformation is underway in the digitization of archives, for example, in that unpublished documents may now become as accessible as published ones. On the other hand, one might well ask whether the reading and study of literature has changed equally abruptly, or at all. Technology evolves quickly but we do not. In the midst of change, more important than the nebulous question of whether there is a revolution or not is the task of determining what is of value - what of the new should be embraced and what of the old preserved. May discretion, not mere expediency, decide.

The shape of the discipline, achievements and prospects, and the navigation of change - these three themes emerged from the Fourth National Conference on the State of Canadian Bibliography and they thread their way through the contents of this special issue of the Papers/Cahiers. For the full fabric I invite you to turn to the essays themselves.

\section{SOMMAIRE}

Les sept articles que nous vous présentons dans cette livraison spéciale des Papers of the Bibliographical Society of Canada / Cabiers de la Société bibliographique du Canada résultent des communications faites lors du Quatrième colloque national sur l'état de la bibliographie canadienne tenu à Bibliothèque et Archives nationales du Québec à Montréal du 20 au 22 juin 2007. Trois questions majeures sont débattues dans ces textes. La première traite des rapports entre la bibliographie et l'histoire du livre. Doit-on aborder ou non ces deux disciplines séparément? On procède en outre à l'évaluation des progrès accomplis récemment par la bibliographie et partant on entrevoit les perspectives qui s'offrent à elle? Et l'on s'interroge enfin sur l'étendue et la profondeur des transformations actuelles réalisées dans le domaine de la technologie informatique. Parle-t-on ici de révolution électronique ou numérique? Tout en apportant des réponses à ces différentes questions, les auteurs de cette série d'articles se livrent à une évaluation de la discipline bibliographique tant dans le domaine de la recherche proprement dite que dans celui de la bibliothéconomie. 